\title{
Yb-Doped $\mathrm{BaCeO}_{3}$ and Its Composite Electrolyte for Intermediate-Temperature Solid Oxide Fuel Cells
}

\author{
Xueyue Jiang, Fufang $\mathrm{Wu}^{*}$ and Hongtao Wang * \\ School of Chemical and Material Engineering, Fuyang Normal College, Anhui Provincial Key Laboratory for \\ Degradation and Monitoring of Pollution of the Environment, Fuyang 236037, China; jiangxueyue@126.com \\ * Correspondence: wff03609344@126.com (F.W.); hwang@fync.edu.cn (H.W.); \\ Tel.: +86-558-2596249 (H.W.); Fax: +86-558-2596703 (H.W.)
}

Received: 25 January 2019; Accepted: 27 February 2019; Published: 4 March 2019

\begin{abstract}
BaCe}_{0.9} \mathrm{Yb}_{0.1} \mathrm{O}_{3-\alpha}$ was prepared via the sol-gel method using zirconium nitrate, ytterbium trioxide, cerium nitrate and barium acetate as raw materials. Subsequently, it reacted with the binary $\mathrm{NaCl} \sim \mathrm{KCl}$ salt to obtain $\mathrm{BaCe}_{0.9} \mathrm{Yb}_{0.1} \mathrm{O}_{3-\alpha}-\mathrm{NaCl} \sim \mathrm{KCl}$ composite electrolyte. The structure, morphology, conductivity and fuel cell performance of the obtained samples were investigated. Scanning electron microscope (SEM) images showed that $\mathrm{BaCe}_{0.9} \mathrm{Yb}_{0.1} \mathrm{O}_{3-\alpha}$ and $\mathrm{NaCl} \mathrm{KCl}$ combined with each other to form a homogeneous 3-D reticulated structure. The highest power density and conductivity of $\mathrm{BaCe}_{0.9} \mathrm{Yb}_{0.1} \mathrm{O}_{3-\alpha}-\mathrm{NaCl} \mathrm{KCl}$ was $393 \mathrm{~mW} \cdot \mathrm{cm}^{-2}$ and $3.0 \times 10^{-1} \mathrm{~S} \cdot \mathrm{cm}^{-1}$ at $700{ }^{\circ} \mathrm{C}$, respectively.
\end{abstract}

Keywords: defects; composite; electrolytes; hydrogen; fuel cell; conductivity

\section{Introduction}

Fuel cells have many merits, such as diversity of fuel options, being environmentally friendly and having high energy efficiency [1-8]. $\mathrm{BaCeO}_{3}$ and $\mathrm{SrCeO}_{3}$-based perovskite oxides have excellent protonic conductivities under hydrogen- or water-containing atmosphere at $400-1000{ }^{\circ} \mathrm{C}$ [9-15]. The oxygen vacancies appear when $\mathrm{Ce}^{4+}$ is substituted with trivalent metal cations [16]. Owing to the concentrations of oxygen vacancies and point defect pairs, two opposing factors, the optimum doping level of $\mathrm{BaCeO}_{3}$ and $\mathrm{SrCeO}_{3}$-based electrolytes is usually $10 \%$ [17]. Among these doped metal cations, $\mathrm{Y}^{3+}$ and $\mathrm{Yb}^{3+}$ doped $\mathrm{BaCeO}_{3}$ or $\mathrm{SrCeO}_{3}$ have relatively high conductivities $[17,18]$. The synthetic methods of $\mathrm{BaCeO}_{3}$ and $\mathrm{SrCeO}_{3}$-based electrolytes are solid-state reactions, citrate-nitrate combustions, microemulsions and sol-gel methods $[19,20]$. The solid-state reaction method requires a high temperature $\left(1550-1700{ }^{\circ} \mathrm{C}\right)$ and the particle size of the product is larger. By comparison, the sol-gel method can mix raw materials at the nanometre level. Moreover, the sintering temperature can be reduced to $200-300{ }^{\circ} \mathrm{C}$.

Intermediate temperature solid oxide fuel cells have many advantages, such as good selectivity, durability and low cost [21-24]. The excellent protonic conduction of $\mathrm{BaCeO}_{3}$-based electrolytes is mainly reflected at high temperatures $\left(700-1000{ }^{\circ} \mathrm{C}\right)$. Also, the conductivities of $\mathrm{BaCeO}_{3}$-based electrolytes are relatively low at intermediate temperatures $\left(400-700{ }^{\circ} \mathrm{C}\right)$. In applying $\mathrm{BaCeO}_{3}$-based electrolytes to intermediate temperature solid oxide fuel cells, electrolyte membranes and composite electrolytes have attracted intensive attention in recent years [25-32]. Park et al. reported that the conductivities of composite $\mathrm{BaZr}_{0.85} \mathrm{Y}_{0.15} \mathrm{O}_{3-\delta}-\mathrm{Nd}_{0.1} \mathrm{Ce}_{0.9} \mathrm{O}_{2-\delta}$ electrolyte are higher than that of single $\mathrm{BaZr}_{0.85} \mathrm{Y}_{0.15} \mathrm{O}_{3-\delta}$ above $600{ }^{\circ} \mathrm{C}$ [28]. Huang et al. found the conductivities of $\mathrm{BaCe}_{0.7} \mathrm{Zr}_{0.1} \mathrm{Y}_{0.2} \mathrm{O}_{3-\delta}-\mathrm{Li}_{2} \mathrm{CO}_{3}-\mathrm{Na}_{2} \mathrm{CO}_{3}$ composite electrolyte $>0.1 \mathrm{~S} \cdot \mathrm{cm}^{-1}$ at $600{ }^{\circ} \mathrm{C}$ [32]. Our previous studies indicated that $\mathrm{SrCeO}_{3}$-based oxides-inorganic salt composite electrolytes have good intermediate temperature electrochemical properties [33,34]. Usually, $\mathrm{BaCeO}_{3}$-based electrolytes 
have higher conductivities than $\mathrm{SrCeO}_{3}$-based ones. To date, there are only a few reports on composite electrolytes of $\mathrm{BaCeO}_{3}$-based ceramic/carbonate [32]. $\mathrm{BaCeO}_{3}$-based electrolytes/chloride composite electrolytes have not been developed and investigated thoroughly.

In this study, $\mathrm{BaCe}_{0.9} \mathrm{Yb}_{0.1} \mathrm{O}_{3-\alpha}$ was prepared via the sol-gel method and the composite electrolyte of $\mathrm{BaCe}_{0.9} \mathrm{Yb}_{0.1} \mathrm{O}_{3-\alpha}-\mathrm{NaCl} \sim \mathrm{KCl}$ was also synthesized. The morphology, physical chemistry change, and the structure of $\mathrm{BaCe}_{0.9} \mathrm{Yb}_{0.1} \mathrm{O}_{3-\alpha}$ were studied using SEM, Thermogravimetric Analysis and Differential Scanning Calorimetry (TGA-DSC) and X-ray diffractometer (XRD). The intermediate temperature electrochemical properties of $\mathrm{BaCe}_{0.9} \mathrm{Yb}_{0.1} \mathrm{O}_{3-\alpha}$ and $\mathrm{BaCe}_{0.9} \mathrm{Yb}_{0.1} \mathrm{O}_{3-\alpha}-\mathrm{NaCl} \sim \mathrm{KCl}$ were also investigated.

\section{Materials and Methods}

$\mathrm{BaCe}_{0.9} \mathrm{Yb}_{0.1} \mathrm{O}_{3-\alpha}$ was prepared via the sol-gel method using zirconium nitrate, ytterbium trioxide, cerium nitrate and barium acetate as the raw materials. The stoichiometric metal ion salts $\left(\mathrm{Ba}^{2+}: \mathrm{Ce}^{4+}: \mathrm{Yb}^{3+}=10: 9: 1\right)$ were dissolved in deionized water. Citric acid was added (three times as much as the metal ion salts). The $p \mathrm{H}$ of the above solution was adjusted to 8.0 with ammonia and heated at $90{ }^{\circ} \mathrm{C}$ for $6 \mathrm{~h}$ until gelatinous. The xerogel was obtained at $130^{\circ} \mathrm{C}$ and heated for the ashing treatment [35-37]. The calcination of the resultant ash was carried out at $1250{ }^{\circ} \mathrm{C}$ and $1550{ }^{\circ} \mathrm{C}$ for $5 \mathrm{~h}$, respectively, to obtain $\mathrm{BaCe}_{0.9} \mathrm{Yb}_{0.1} \mathrm{O}_{3-\alpha}$.

A 1:1 mole ratio of $\mathrm{NaCl}$ to $\mathrm{KCl}$ was heated at $700{ }^{\circ} \mathrm{C}$ to form the molten salt [38]. The weight ratio of $\mathrm{BaCe}_{0.9} \mathrm{Yb}_{0.1} \mathrm{O}_{3-\alpha}: \mathrm{NaCl} \sim \mathrm{KCl}=80: 20$ was mixed and ground. Then, the mixing powders were sintered at $750{ }^{\circ} \mathrm{C}$ for $2 \mathrm{~h}$ to obtain $\mathrm{BaCe}_{0.9} \mathrm{Yb}_{0.1} \mathrm{O}_{3-\alpha}-\mathrm{NaCl} \mathrm{KCl}$.

Thermogravimetric Analysis and Differential Scanning Calorimetry (TGA-DSC, Universal V 3.7A, TA Instruments, New Castle, DE, USA) were conducted before and after the ashing treatment of the $\mathrm{BaCe}_{0.9} \mathrm{Yb}_{0.1} \mathrm{O}_{3-\alpha}$ precursor. The temperature ranged between $25^{\circ} \mathrm{C}$ and $1100{ }^{\circ} \mathrm{C}$ with a heating rate of $15^{\circ} \mathrm{C} \cdot \mathrm{min}^{-1}$. The structures of $\mathrm{BaCe}_{0.9} \mathrm{Yb}_{0.1} \mathrm{O}_{3-\alpha}\left(1250{ }^{\circ} \mathrm{C}, 1550{ }^{\circ} \mathrm{C}\right)$ and $\mathrm{BaCe}_{0.9} \mathrm{Yb}_{0.1} \mathrm{O}_{3-\alpha}-\mathrm{NaCl} \sim \mathrm{KCl}$ were determined by X-ray diffractometer (XRD, X'pert Pro MPD, Holland's company, Amsterdam, Netherlands). From the $\mathrm{X}$-ray spectrogram, the average crystallite size $\left(\mathrm{D}_{\mathrm{XRD}}\right)$ can be calculated from:

$$
\mathrm{D}_{\mathrm{XRD}}=0.89 \lambda / \mathrm{b} \cos \theta
$$

where $\lambda$ is the $\mathrm{X}$-ray wavelength of $\mathrm{Cu}-\mathrm{K} \alpha$ radiation $(\lambda=0.15405 \mathrm{~nm}), \mathrm{b}$ is the corrected half-width of the diffraction peak and $\theta$ is the diffraction angle $\left(^{\circ}\right)$ [35]. The external and cross-sectional surfaces of $\mathrm{BaCe}_{0.9} \mathrm{Yb}_{0.1} \mathrm{O}_{3-\alpha}\left(1550{ }^{\circ} \mathrm{C}\right)$ and $\mathrm{BaCe}_{0.9} \mathrm{Yb}_{0.1} \mathrm{O}_{3-\alpha}-\mathrm{NaCl} \mathrm{KCl}$ were imaged using a scanning electron microscope (SEM, S-4700, Hitachi, Tokyo, Japan).

For conductivity measurements, $\mathrm{BaCe}_{0.9} \mathrm{Yb}_{0.1} \mathrm{O}_{3-\alpha}\left(1550{ }^{\circ} \mathrm{C}\right)$ and $\mathrm{BaCe}_{0.9} \mathrm{Yb}_{0.1} \mathrm{O}_{3-\alpha}-\mathrm{NaCl} \sim \mathrm{KCl}$ pellets were processed into wafers (diameter $=16 \mathrm{~mm}$, thickness $=1.0 \mathrm{~mm}$ ). The electrodes (area $=0.50 \mathrm{~cm}^{2}$ ) were comprised of $20 \mathrm{wt} \% \mathrm{Pd}$ and $80 \mathrm{wt} \% \mathrm{Ag}$ and the wires were pure $\mathrm{Ag}$. The conductivities were investigated utilizing an electrochemical analyzer over the frequency range from $1 \mathrm{~Hz}$ to $100 \mathrm{KHz}$ in the air at $400-700{ }^{\circ} \mathrm{C}$ as well as with the oxygen partial pressures $\left(p \mathrm{O}_{2}\right)$ from $1 \times 10^{-20}$ to $1 \mathrm{~atm}$ at $700{ }^{\circ} \mathrm{C}$ [8]. The electrochemical impedance spectroscopy (EIS) of $\mathrm{BaCe}_{0.9} \mathrm{Yb}_{0.1} \mathrm{O}_{3-\alpha}\left(1550{ }^{\circ} \mathrm{C}\right)$ and $\mathrm{BaCe}_{0.9} \mathrm{Yb}_{0.1} \mathrm{O}_{3-\alpha}-\mathrm{NaCl} \sim \mathrm{KCl}$ were studied under open circuit conditions. Finally, $\mathrm{H}_{2} / \mathrm{O}_{2}$ fuel cells were fabricated and tested.

\section{Results and Discussion}

TGA-DSC plots for the $\mathrm{BaCe}_{0.9} \mathrm{Yb}_{0.1} \mathrm{O}_{3-\alpha}$ precursor were measured before and after the ashing treatment. In Figure 1a, the DSC curve has a sharp exothermic peak between $260{ }^{\circ} \mathrm{C}$ and $300{ }^{\circ} \mathrm{C}$ accompanied by $45 \%$ weight loss, mainly attributed to the decomposition of citric acid and ammonium salt. The weight loss is gentle, declining from $510^{\circ} \mathrm{C}$ to $580^{\circ} \mathrm{C}$, which is attributed to the decomposition of the nitrate. As seen in Figure 1b, there was a decline in weight loss around $550{ }^{\circ} \mathrm{C}$, which is ascribed 
to the incomplete decomposition of the nitrate [39,40]. There was almost no weight loss after $1070{ }^{\circ} \mathrm{C}$ indicating that the $\mathrm{BaCeO}_{3}$ phase had begun to form.
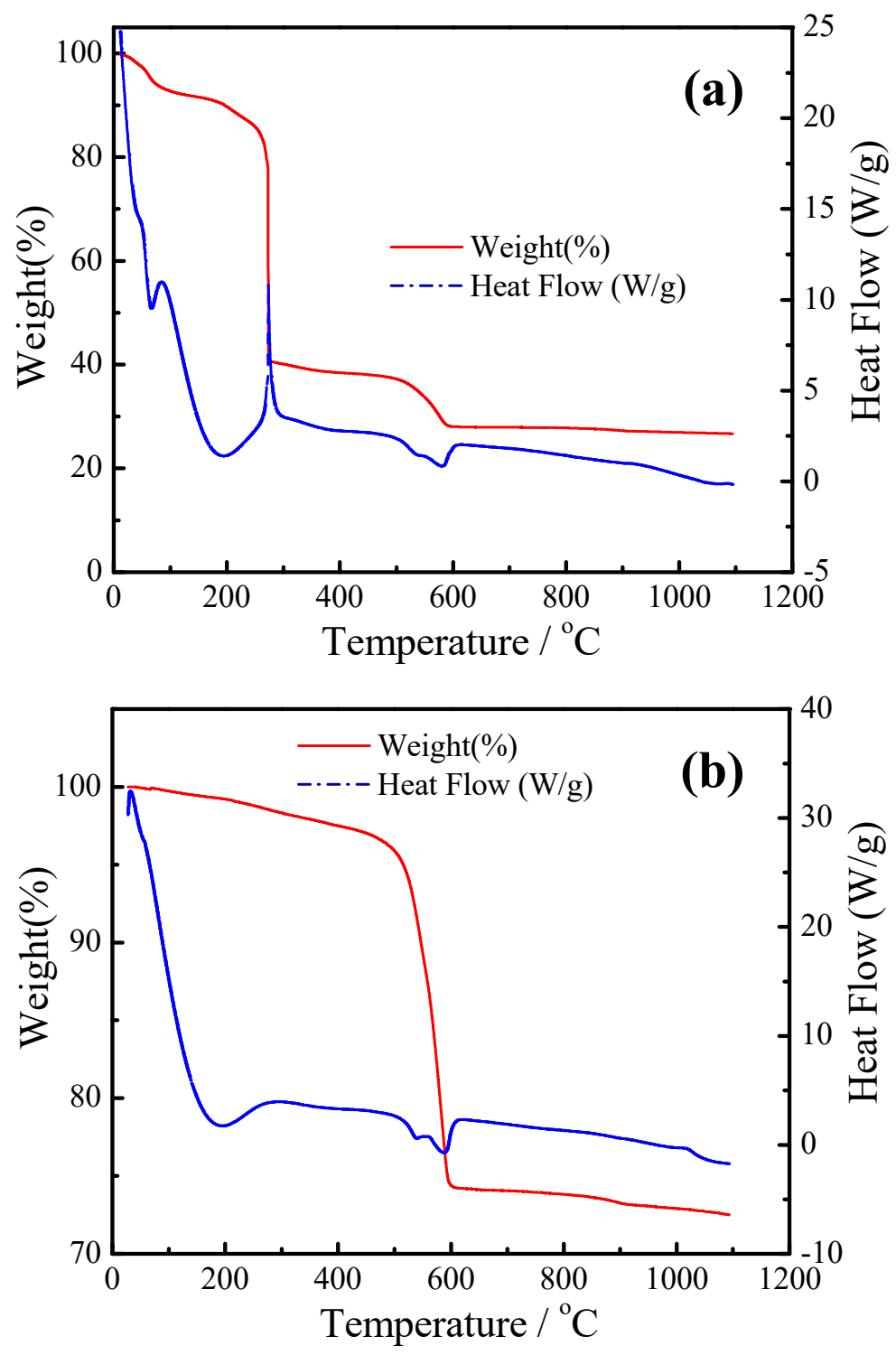

Figure 1. Thermogravimetric Analysis and Differential Scanning Calorimetry (TGA-DSC) plots for the $\mathrm{BaCe}_{0.9} \mathrm{Yb}_{0.1} \mathrm{O}_{3-\alpha}$ precursor before (a) and after (b) ashing treatment.

The XRD patterns of $\mathrm{BaCe}_{0.9} \mathrm{Yb}_{0.1} \mathrm{O}_{3-\alpha}\left(1250{ }^{\circ} \mathrm{C}, 1550{ }^{\circ} \mathrm{C}\right)$ and $\mathrm{BaCe}_{0.9} \mathrm{Yb}_{0.1} \mathrm{O}_{3-\alpha}-\mathrm{NaCl} \mathrm{KCl}$ are shown in Figure 2. The XRD patterns show that the sintered $\mathrm{BaCe}_{0.9} \mathrm{Yb}_{0.1} \mathrm{O}_{3-\alpha}\left(1250{ }^{\circ} \mathrm{C}, 1550{ }^{\circ} \mathrm{C}\right)$ samples are all orthorhombic $\mathrm{BaCeO}_{3}$ phases. The average crystallite sizes $\left(\mathrm{D}_{\mathrm{XRD}}\right)$ of $\mathrm{BaCe}_{0.9} \mathrm{Yb}_{0.1} \mathrm{O}_{3-\alpha}$ $\left(1250^{\circ} \mathrm{C}, 1550{ }^{\circ} \mathrm{C}\right)$ samples are $45.9573 \mathrm{~nm}$ and $50.2176 \mathrm{~nm}$, respectively. Combined with the results of Figure 1 , the first sintering temperature of $1250{ }^{\circ} \mathrm{C}$ is suitable. There are some small additional peaks in the $\mathrm{BaCe}_{0.9} \mathrm{Yb}_{0.1} \mathrm{O}_{3-\alpha}-\mathrm{NaCl} \sim \mathrm{KCl}$ XRD spectrum, suggesting that $\mathrm{NaCl} \sim \mathrm{KCl}$ inorganic salts exist as crystalline phases in the composite electrolyte [35].

The SEM external and cross-sectional surface images of $\mathrm{BaCe}_{0.9} \mathrm{Yb}_{0.1} \mathrm{O}_{3-\alpha}$ calcined at $1550{ }^{\circ} \mathrm{C}$ for $5 \mathrm{~h}$ (Figure 3a,b) and $\mathrm{BaCe}_{0.9} \mathrm{Yb}_{0.1} \mathrm{O}_{3-\alpha}-\mathrm{NaCl} \mathrm{KCl}$ sintered at $750{ }^{\circ} \mathrm{C}$ for $2 \mathrm{~h}$ (Figure $3 \mathrm{c}, \mathrm{d}$ ) are displayed in Figure 3. As seen in Figure $3 a, b$, the degree of $\mathrm{BaCe}_{0.9} \mathrm{Yb}_{0.1} \mathrm{O}_{3-\alpha}$ particle agglomeration is good. However, the fractured surface image of $\mathrm{BaCe}_{0.9} \mathrm{Yb}_{0.1} \mathrm{O}_{3-\alpha}$ shows that there are still some holes after being calcined at $1550{ }^{\circ} \mathrm{C}$ for $5 \mathrm{~h}$, as shown in Figure $3 \mathrm{~b}$. It has been proved by our experiments that they are closed holes. In Figure $3 c, d$, it is clearly visible that the particles of $\mathrm{BaCe}_{0.9} \mathrm{Yb}_{0.1} \mathrm{O}_{3-\alpha}$ 
are aggregated into clumps after the addition of $\mathrm{NaCl} \sim \mathrm{KCl}$ inorganic salts sintered at $750{ }^{\circ} \mathrm{C}$ for $2 \mathrm{~h}$. The regular polyhedron zones correspond to the $\mathrm{BaCe}_{0.9} \mathrm{Yb}_{0.1} \mathrm{O}_{3-\alpha}$. Contrastingly, the amorphous areas point to the $\mathrm{NaCl} \sim \mathrm{KCl}$ inorganic salt phase. Combined with the results of Figure $2, \mathrm{NaCl} \sim \mathrm{KCl}$ inorganic salts exist as both crystalline and amorphous phases [31,32].

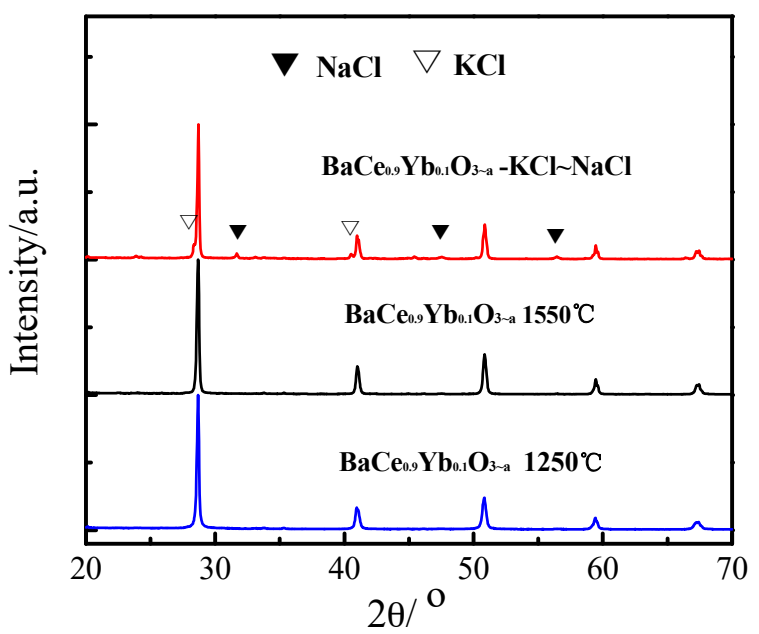

Figure 2. $\mathrm{X}$-ray diffractometer (XRD) patterns of $\mathrm{BaCe}_{0.9} \mathrm{Yb}_{0.1} \mathrm{O}_{3-\alpha}\left(1250{ }^{\circ} \mathrm{C}, 1550{ }^{\circ} \mathrm{C}\right)$ and $\mathrm{BaCe}_{0.9} \mathrm{Yb}_{0.1} \mathrm{O}_{3-\alpha}-\mathrm{NaCl} \sim \mathrm{KCl}$.
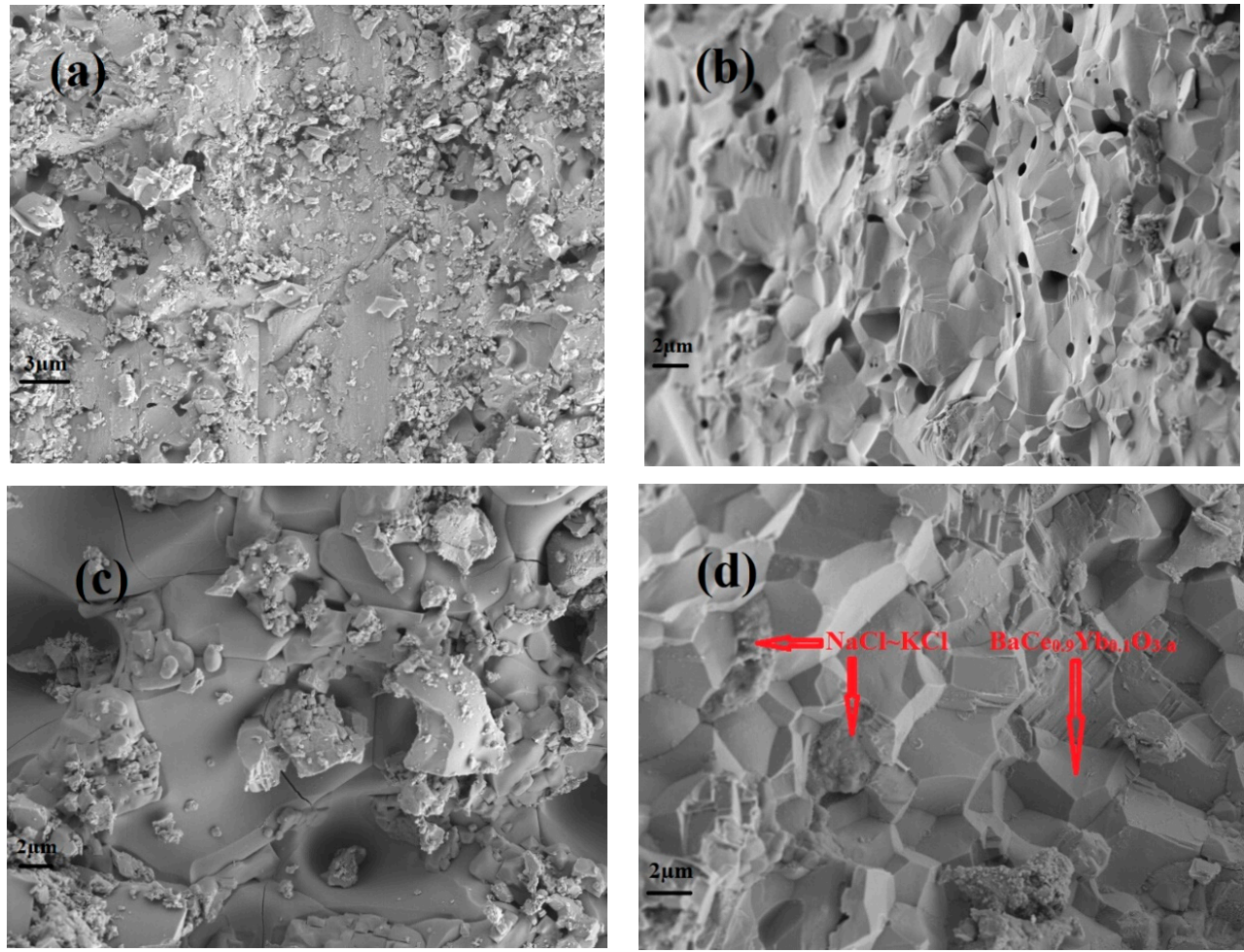

Figure 3. Scanning electron microscope (SEM) photos of $\mathrm{BaCe}_{0.9} \mathrm{Yb}_{0.1} \mathrm{O}_{3-\alpha}$ calcined at $1550{ }^{\circ} \mathrm{C}$ for $5 \mathrm{~h}$ $(\mathbf{a}, \mathbf{b})$ external and cross-sectional surfaces, and $\mathrm{BaCe}_{0.9} \mathrm{Yb}_{0.1} \mathrm{O}_{3-\alpha}-\mathrm{NaCl} \sim \mathrm{KCl}$ sintered at $750{ }^{\circ} \mathrm{C}$ for $2 \mathrm{~h}$ (c,d) external and cross-sectional surfaces.

Figure 4 shows the $\log (\sigma \mathrm{T}) \sim 1000 \mathrm{~T}^{-1}$ plots of $\mathrm{BaCe}_{0.9} \mathrm{Yb}_{0.1} \mathrm{O}_{3-\alpha}\left(1550{ }^{\circ} \mathrm{C}\right)$ and $\mathrm{BaCe}_{0.9} \mathrm{Yb}_{0.1} \mathrm{O}_{3-\alpha^{-}}$ $\mathrm{NaCl} \mathrm{KCl}$ in the air from $400{ }^{\circ} \mathrm{C}$ to $700{ }^{\circ} \mathrm{C}$. As seen in Figure 4, the conductivities of composite $\mathrm{BaCe}_{0.9} \mathrm{Yb}_{0.1} \mathrm{O}_{3-\alpha}-\mathrm{NaCl} \mathrm{KCl}$ electrolytes are higher than that of the single $\mathrm{BaCe}_{0.9} \mathrm{Yb}_{0.1} \mathrm{O}_{3-\alpha}$. The conductivities of $\mathrm{BaCe}_{0.9} \mathrm{Yb}_{0.1} \mathrm{O}_{3-\alpha}-\mathrm{NaCl} \mathrm{KCl}$ vary from $2.0 \times 10^{-4} \mathrm{~S} \cdot \mathrm{cm}^{-1}$ to $3.0 \times 10^{-1} \mathrm{~S} \cdot \mathrm{cm}^{-1}$ 
in the range of $400-700{ }^{\circ} \mathrm{C}$ which is equivalent to $\mathrm{BaZr}_{0.85} \mathrm{Y}_{0.15} \mathrm{O}_{3-\alpha}-\mathrm{Li}_{2} \mathrm{CO}_{3}-\mathrm{K}_{2} \mathrm{CO}_{3}$ in the air at $650{ }^{\circ} \mathrm{C}$ [31]. The single $\mathrm{BaCe}_{0.9} \mathrm{Yb}_{0.1} \mathrm{O}_{3-\alpha}$ electrolyte shows a linear Arrhenius curve in the air at $400-700{ }^{\circ} \mathrm{C}$, whereas the conductivities of $\mathrm{BaZr}_{0.85} \mathrm{Y}_{0.15} \mathrm{O}_{3-\alpha}-\mathrm{Li}_{2} \mathrm{CO}_{3}-\mathrm{K}_{2} \mathrm{CO}_{3}$ start to increase dramatically above $600{ }^{\circ} \mathrm{C}$. The results indicate that the molten $\mathrm{NaCl} \sim \mathrm{KCl}$ salt provides more ion transport channels at high temperatures [31,32,41].

Figure 5 shows the conductivities of $\mathrm{BaCe}_{0.9} \mathrm{Yb}_{0.1} \mathrm{O}_{3-\alpha}\left(1550{ }^{\circ} \mathrm{C}\right)$ and $\mathrm{BaCe}_{0.9} \mathrm{Yb}_{0.1} \mathrm{O}_{3-\alpha^{-}}$ $\mathrm{NaCl} \mathrm{KCl}$ as a function of $p \mathrm{O}_{2}$ from $1 \times 10^{-20}$ to $1 \mathrm{~atm}$ at $700{ }^{\circ} \mathrm{C}$. The $\log \sigma \sim \log p \mathrm{O}_{2}$ plot is usually used to estimate the ionic and electronic conduction of an electrolyte. Pikalova et al. reported that $\mathrm{BaCe}_{0.89} \mathrm{Gd}_{0.1} \mathrm{Cu}_{0.01} \mathrm{O}_{3-\alpha}$ has a predominantly proton-conducting character at intermediate and low $\mathrm{pO}_{2}$ values [9]. As shown in Figure 5, the conductivity is a horizontal line parallel to the X-axis, which indicates that the samples are almost pure ionic conductors. This may be ascribed to the molten salts acting as fast conduction paths for ionic charge carriers, which corresponds with related reports on composite electrolytes [25-32].

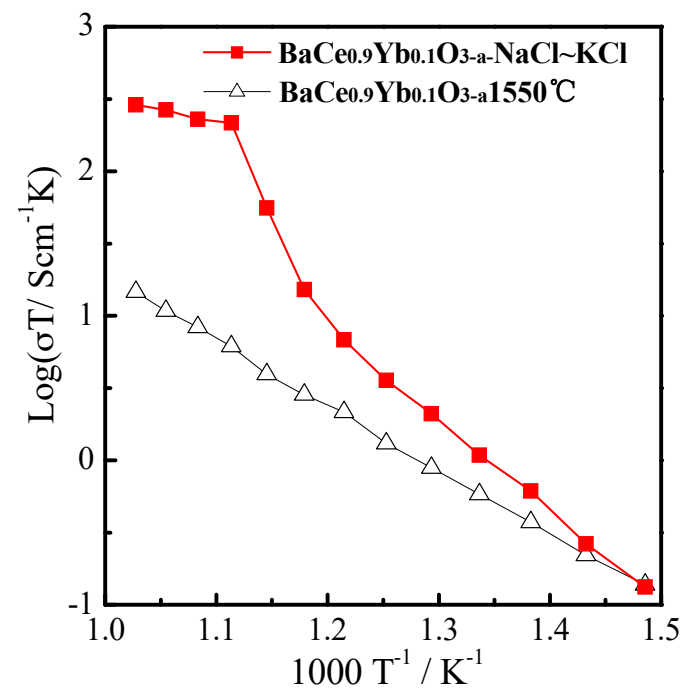

Figure 4. The $\log (\sigma \mathrm{T}) \sim 1000 \mathrm{~T}^{-1}$ plots of $\mathrm{BaCe}_{0.9} \mathrm{Yb}_{0.1} \mathrm{O}_{3-\alpha}\left(1550{ }^{\circ} \mathrm{C}\right)$ and $\mathrm{BaCe}_{0.9} \mathrm{Yb}_{0.1} \mathrm{O}_{3-\alpha^{-}}$ $\mathrm{NaCl} \mathrm{KCl}$ in the air from $400{ }^{\circ} \mathrm{C}$ to $700{ }^{\circ} \mathrm{C}$.

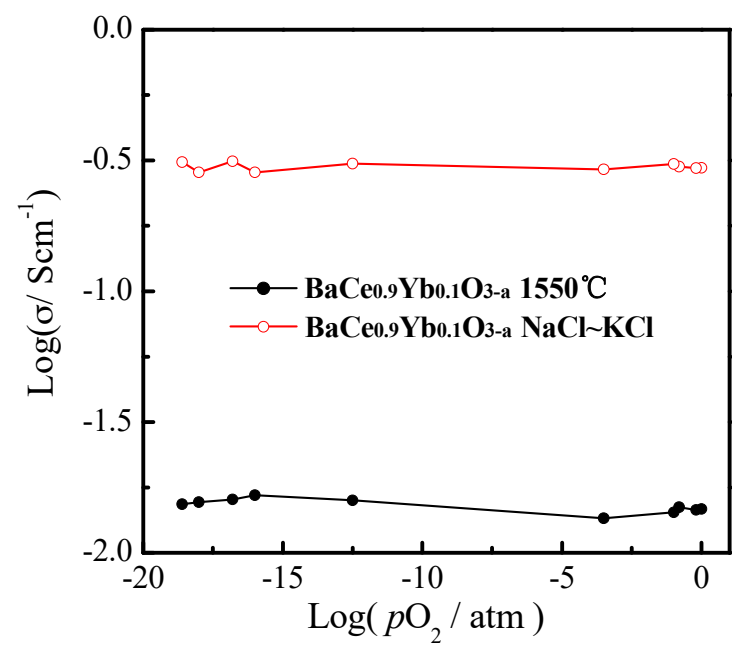

Figure 5. The conductivities of $\mathrm{BaCe}_{0.9} \mathrm{Yb}_{0.1} \mathrm{O}_{3-\alpha}\left(1550{ }^{\circ} \mathrm{C}\right)$ and $\mathrm{BaCe}_{0.9} \mathrm{Yb}_{0.1} \mathrm{O}_{3-\alpha}-\mathrm{NaCl} \mathrm{KCl}$ as a function of $p \mathrm{O}_{2}$ at $700{ }^{\circ} \mathrm{C}$.

Figure 6 presents the electrochemical impedance spectroscopy (EIS) of $\mathrm{BaCe}_{0.9} \mathrm{Yb}_{0.1} \mathrm{O}_{3-\alpha}\left(1550{ }^{\circ} \mathrm{C}\right)$ and $\mathrm{BaCe}_{0.9} \mathrm{Yb}_{0.1} \mathrm{O}_{3-\alpha}-\mathrm{NaCl} \mathrm{KCl}$ under open-circuit conditions at $700{ }^{\circ} \mathrm{C}$. Usually, the AC impedance curve includes a semicircle and a radial at high $(1 \mathrm{KHz}-100 \mathrm{KHz})$ and low $(1 \mathrm{~Hz}-1 \mathrm{KHz})$ frequencies 
which correspond to the ohmic and total resistances, respectively. Additionally, the difference between them from the intercept with the real axis at high frequencies to the juncture point of the semicircle and radial, represents polarization resistance $\left(R_{\mathrm{p}}\right)$ [18]. The semicircle gradually disappears as the temperature increases [42,43]. In Figure 6, the polarization resistance $\left(R_{\mathrm{p}}\right)$ for $\mathrm{BaCe}_{0.9} \mathrm{Yb}_{0.1} \mathrm{O}_{3-\alpha}$ $\left(1550{ }^{\circ} \mathrm{C}\right)$ and $\mathrm{BaCe}_{0.9} \mathrm{Yb}_{0.1} \mathrm{O}_{3-\alpha}-\mathrm{NaCl} \mathrm{KCl}$ are $1.72 \Omega \cdot \mathrm{cm}^{2}$ and $0.31 \Omega \cdot \mathrm{cm}^{2}$, respectively. This result indicates that the molten salt cannot only generate fast transport ways but also enhance its long-range mobility, which leads to lower resistance and higher performance.

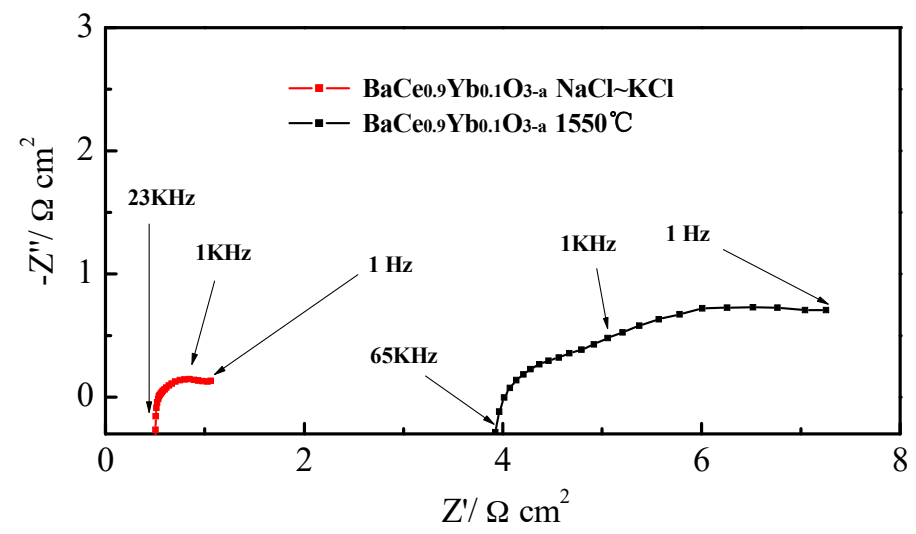

Figure 6. The electrochemical impedance spectroscopy (EIS) of $\mathrm{BaCe}_{0.9} \mathrm{Yb}_{0.1} \mathrm{O}_{3-\alpha}\left(1550{ }^{\circ} \mathrm{C}\right)$ and $\mathrm{BaCe}_{0.9} \mathrm{Yb}_{0.1} \mathrm{O}_{3-\alpha}-\mathrm{NaCl} \mathrm{KCl}$ under open-circuit conditions at $700{ }^{\circ} \mathrm{C}$.

Figure 7 shows the $\mathrm{I}-V-P$ curves of $\mathrm{BaCe}_{0.9} \mathrm{Yb}_{0.1} \mathrm{O}_{3-\alpha}\left(1550{ }^{\circ} \mathrm{C}\right)$ and $\mathrm{BaCe}_{0.9} \mathrm{Yb}_{0.1} \mathrm{O}_{3-\alpha}-\mathrm{NaCl} \mathrm{KCl}$ at $700{ }^{\circ} \mathrm{C}$. The following reactions occur in the cathode and anode compartments:

$$
\text { cathode reaction: } 2 \mathrm{H}^{+}+\mathrm{O}_{2}+4 \mathrm{e}^{-}=\mathrm{H}_{2} \mathrm{O}+\mathrm{O}^{2-}
$$

and

$$
\text { anode reaction: } 2 \mathrm{H}_{2}+\mathrm{O}^{2-}=2 \mathrm{H}^{+}+\mathrm{H}_{2} \mathrm{O}+4 \mathrm{e}^{-} \text {. }
$$

The $\mathrm{H}_{2} / \mathrm{O}_{2}$ fuel cell using $\mathrm{BaCe}_{0.9} \mathrm{Yb}_{0.1} \mathrm{O}_{3-\alpha}-\mathrm{NaCl} \sim \mathrm{KCl}$ (thickness $=1.0 \mathrm{~mm}$ ) as electrolyte achieves the highest power density $\left(P_{\mathrm{h}}\right)$ of $393 \mathrm{~mW} \cdot \mathrm{cm}^{-2}$ when the voltage is $0.64 \mathrm{~V}$ at $700{ }^{\circ} \mathrm{C}$. The $\mathrm{SrCe}_{0.6} \mathrm{Zr}_{0.3} \mathrm{Lu}_{0.1} \mathrm{O}_{3-\alpha}$ only has $34.8 \mathrm{~mW} \cdot \mathrm{cm}^{-2}$ under the same conditions. The $P_{\mathrm{h}}$ value of our result is higher than the fuel cell performance of $60 \mathrm{wt} \% \mathrm{Ce}_{0.8} \mathrm{Sm}_{0.2} \mathrm{O}_{1.9}-40 \mathrm{wt} \%(\mathrm{Li} / \mathrm{Na})_{2} \mathrm{CO}_{3}$ $\left(575{ }^{\circ} \mathrm{C}\right.$ ) and $\mathrm{BaCe}_{0.7} \mathrm{In}_{0.15} \mathrm{Ta}_{0.05} \mathrm{Y}_{0.1} \mathrm{O}_{3-\delta}$ (thickness $=25 \mu \mathrm{m}, 700{ }^{\circ} \mathrm{C}$ ), however, lower than $80 \mathrm{wt} \%$ $\mathrm{BaCe}_{0.7} \mathrm{Zr}_{0.1} \mathrm{Y}_{0.2} \mathrm{O}_{3-\delta}-20 \mathrm{wt} \%(\mathrm{Li} / \mathrm{Na})_{2} \mathrm{CO}_{3}$ (thickness $=0.4 \mathrm{~mm}, 600{ }^{\circ} \mathrm{C}$ ) as shown in Table $1[18,32,44]$. This may be due to the different electrolyte and inorganic salt types and fuel cell construction.

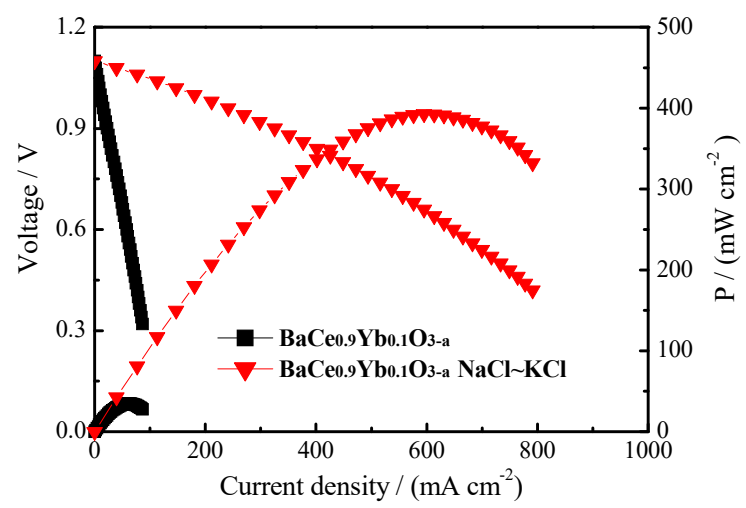

Figure 7. The $I-V-P$ curves of $\mathrm{BaCe}_{0.9} \mathrm{Yb}_{0.1} \mathrm{O}_{3-\alpha}\left(1550{ }^{\circ} \mathrm{C}\right)$ and $\mathrm{BaCe}_{0.9} \mathrm{Yb}_{0.1} \mathrm{O}_{3-\alpha}-\mathrm{NaCl} \sim \mathrm{KCl}$ at $700{ }^{\circ} \mathrm{C}$. 
Table 1. The highest power densities of $\mathrm{BaCe}_{0.9} \mathrm{Yb}_{0.1} \mathrm{O}_{3-\alpha}-\mathrm{NaCl} \mathrm{KCl}$ and similar electrolytes in the literature.

\begin{tabular}{cc}
\hline Electrolytes & Highest Power Densities \\
\hline $\mathrm{BaCe}_{0.9} \mathrm{Yb}_{0.1} \mathrm{O}_{3-\alpha}-\mathrm{NaCl} \mathrm{KCl}(80: 20)$ & $393 \mathrm{~mW} \cdot \mathrm{cm}^{-2}$ (thickness $\left.=1.0 \mathrm{~mm}\right), 700{ }^{\circ} \mathrm{C}$, in this work \\
$\mathrm{BaCe}_{0.7} \mathrm{Zr}_{0.1} \mathrm{Y}_{0.2} \mathrm{O}_{3-\delta}-(\mathrm{Li} / \mathrm{Na})_{2} \mathrm{CO}_{3}(80: 20)$ & $957 \mathrm{~mW} \cdot \mathrm{cm}^{-2}$ (thickness $\left.=0.4 \mathrm{~mm}\right), 600{ }^{\circ} \mathrm{C},[32]$ \\
$\mathrm{Ce}_{0.8} \mathrm{Sm}_{0.2} \mathrm{O}_{1.9}-(\mathrm{Li} / \mathrm{Na})_{2} \mathrm{CO}_{3}(60: 40)$ & $240 \mathrm{~mW} \cdot \mathrm{cm}^{-2}, 575{ }^{\circ} \mathrm{C},[44]$ \\
$\mathrm{BaCe}_{0.7} \mathrm{In}_{0.15} \mathrm{Ta}_{0.05} \mathrm{Y}_{0.1} \mathrm{O}_{3-\delta}$ & $303 \mathrm{~mW} \cdot \mathrm{cm}^{-2}$ (thickness $\left.=25 \mu \mathrm{m}\right), 700{ }^{\circ} \mathrm{C},[18]$ \\
\hline
\end{tabular}

\section{Conclusions}

In this study, $\mathrm{BaCe}_{0.9} \mathrm{Yb}_{0.1} \mathrm{O}_{3-\alpha}$ was prepared via the sol-gel method. The first sintering temperature for the $\mathrm{BaCe}_{0.9} \mathrm{Yb}_{0.1} \mathrm{O}_{3-\alpha}$ precursor was determined using TGA-DSC. XRD and SEM results indicated that $\mathrm{NaCl} \sim \mathrm{KCl}$ inorganic salts exist as both crystalline and amorphous phases. The polarization resistances $\left(R_{\mathrm{p}}\right)$ for $\mathrm{BaCe}_{0.9} \mathrm{Yb}_{0.1} \mathrm{O}_{3-\alpha}\left(1550{ }^{\circ} \mathrm{C}\right)$ and $\mathrm{BaCe}_{0.9} \mathrm{Yb}_{0.1} \mathrm{O}_{3-\alpha}-\mathrm{NaCl} \mathrm{KCl}$ were $1.72 \Omega \cdot \mathrm{cm}^{2}$ and $0.31 \Omega \cdot \mathrm{cm}^{2}$ under open-circuit conditions at $700{ }^{\circ} \mathrm{C}$, respectively. The highest power density and conductivity of $\mathrm{BaCe}_{0.9} \mathrm{Yb}_{0.1} \mathrm{O}_{3-\alpha}-\mathrm{NaCl} \mathrm{KCl}$ were $393 \mathrm{~mW} \cdot \mathrm{cm}^{-2}$ and $3.0 \times 10^{-1} \mathrm{~S} \cdot \mathrm{cm}^{-1}$ at $700{ }^{\circ} \mathrm{C}$, respectively.

Author Contributions: H.W. and X.J. conceived and designed the experiments; F.W. and X.J. performed the experiments; H.W. and F.W. analyzed the data; X.J. contributed the used materials and analysis tools; H.W. wrote the paper.

Funding: This work was supported by the National Natural Science Foundation (No. 51402052, 21602029) of China, The Natural Science Project of Anhui Province (No. KJ2018A0337), Excellent Youth Foundation of Anhui Educational Committee (No. gxyq2018046), Horizontal cooperation project of Fuyang municipal government and Fuyang Normal College (No. XDHX2016019, XDHXTD201704).

Conflicts of Interest: The authors declare no conflict of interest.

\section{References}

1. Lo Faro, M.; Trocino, S.; Zignani, S.C.; Italiano, C.; Vita, A.; Aricò, A.S. Study of a solid oxide fuel cell fed with n-dodecane reformate. Part II: Effect of the reformate composition. Int. J. Hydrog. Energy 2017, 42, 1751-1757.

2. Fragiacomo, P.; De. Lorenzo, G.; Corigliano, O. Performance Analysis of an intermediate temperature solid oxide electrolyzer test bench under a $\mathrm{CO}_{2}-\mathrm{H}_{2} \mathrm{O}$ feed stream. Energies 2018, 11, 2276. [CrossRef]

3. Yang, C.; Ren, C.; Yu, L.; Jin, C. High performance intermediate temperature micro-tubular SOFCs with $\mathrm{Ba}_{0.9} \mathrm{Co}_{0.7} \mathrm{Fe}_{0.2} \mathrm{Nb}_{0.1} \mathrm{O}_{3-\delta}$ as cathode. Int. J. Hydrog. Energy 2013, 38, 15348-15353. [CrossRef]

4. Miyake, M.; Matsumoto, S.; Iwami, M.; Nishimoto, S.; Kameshima, Y. Electrochemical performances of $\mathrm{Ni}_{1-x} \mathrm{Cu}_{x} / \mathrm{SDC}$ cermet anodes for intermediate-temperature SOFCs using syngas fuel. Int. J. Hydrog. Energy 2016, 41, 13625-13631. [CrossRef]

5. De. Lorenzo, G.; Fragiacomo, P. Electrical and thermal analysis of an intermediate temperature IIR-SOFC system fed by biogas. Energy Sci. Eng. 2018, 6, 60-72. [CrossRef]

6. Milewski, J.; Wołowicz, M.; Lewandowski, J. Comparison of SOE/SOFC system configurations for a peak hydrogen power plant. Int. J. Hydrog. Energy 2017, 42, 3498-3509. [CrossRef]

7. Kim, H.-S.; Bae, H.B.; Jung, W.; Chung, S.-Y. Manipulation of nanoscale intergranular phases for high proton conduction and decomposition tolerance in $\mathrm{BaCeO}_{3}$ polycrystals. Nano Lett. 2018, 18, 1110-1117. [CrossRef] [PubMed]

8. Gong, Z.; Sun, W.; Jin, Z.; Miao, L.; Liu, W. Barium- and strontium-containing anode materials toward ceria-based solid oxide fuel cells with high open circuit voltages. ACS Appl. Energy Mater. 2018, 1, 3521-3528. [CrossRef]

9. Pikalova, E.; Medvedev, D. Effect of anode gas mixture humidification on the electrochemical performance of the $\mathrm{BaCeO}_{3}$-based protonic ceramic fuel cell. Int. J. Hydrog. Energy 2016, 41, 4016-4025. [CrossRef]

10. Bae, S.Y.; Park, J.-Y.; Lim, H.-T. Investigation of electronic transport property and durability of BCY-BZY electrolyte cells using embedded probes. Electrochim. Acta 2017, 236, 399-407. [CrossRef] 
11. Sun, H.; Zhang, S.; Li, C.; Rainwater, B.; Liu, Y.; Zhang, L.; Zhang, Y.; Li, C.; Liu, M. Atmospheric plasma-sprayed $\mathrm{BaZr}_{0.1} \mathrm{Ce}_{0.7} \mathrm{Y}_{0.1} \mathrm{Yb}_{0.1} \mathrm{O}_{3-\delta}(\mathrm{BZCYYb})$ electrolyte membranes for intermediate- temperature solid oxide fuel cells. Ceram. Int. 2016, 42, 19231-19236. [CrossRef]

12. Danilov, N.; Pikalova, E.; Lyagaeva, J.; Antonov, B.; Medvedev, D.; Demin, A.; Tsiakaras, P. Grain and grain boundary transport in $\mathrm{BaCe}_{0.5} \mathrm{Zr}_{0.3} \mathrm{Ln}_{0.2} \mathrm{O}_{3-\delta}(\mathrm{Ln}-\mathrm{Y}$ or lanthanide) electrolytes attractive for protonic ceramic fuel cells application. J. Power Sources 2017, 366, 161-168. [CrossRef]

13. Xiao, J.; Chen, L.; Yuan, H.; Ji, L.; Xiong, C.; Ma, J.; Zhu, X. Fabrication and characterization of $\mathrm{BaZr}_{0.1} \mathrm{Ce}_{0.7} \mathrm{Y}_{0.2} \mathrm{O}_{3-\delta}$ based anode supported solid oxide fuel cells by tape casting combined with spray coating. Mater. Lett. 2017, 189, 192-195. [CrossRef]

14. Lyagaeva, J.; Vdovin, G.; Hakimova, L.; Medvedev, D.; Demin, A.; Tsiakaras, P. BaCe $\mathrm{B}_{0.5} \mathrm{Zr}_{0.3} \mathrm{Y}_{0.2-\mathrm{x}} \mathrm{Yb}_{\mathrm{x}} \mathrm{O}_{3-\delta}$ proton-conducting electrolytes for intermediate-temperature solid oxide fuel cells. Electrochim. Acta 2017, 251, 554-561. [CrossRef]

15. Wang, W.; Medvedev, D.; Shao, Z. Gas humidification impact on the properties and performance of perovskite-type functional materials in proton-conducting solid oxide cells. Adv. Funct. Mater. 2018, 1802592. [CrossRef]

16. Minakshi, M.; Nallathamby, K.; Mitchell, D.R.G. Electrochemical characterization of an aqueous lithium rechargeable battery: The effect of $\mathrm{CeO}_{2}$ additions to the $\mathrm{MnO}_{2}$ cathode. J. Alloy Compd. 2009, 479, 87-90. [CrossRef]

17. Sun, L.; Miao, H.; Wang, H. Novel $\mathrm{SrCe}_{1-x} \mathrm{YbxO}_{3-\alpha}-(\mathrm{Na} / \mathrm{K}) \mathrm{Cl}$ composite electrolytes for intermediate temperature solid oxide fuel cells. Solid State Ion. 2017, 311, 41-45. [CrossRef]

18. Zhang, Z.; Chen, L.; Li, Q.; Song, T.; Su, J.; Cai, B.; He, H. High performance In, Ta and Y-doped $\mathrm{BaCeO}_{3}$ electrolyte membrane for proton-conducting solid oxide fuel cells. Solid State Ion. 2018, 323, 25-31. [CrossRef]

19. Wang, H.; Han, Y.; Shi, R.; Sheng, L.; Guan, Q.; Liu, J. BaCe ${ }_{0.9} \mathrm{Er}_{0.1} \mathrm{O}_{3-\alpha}-\mathrm{NaCl}-\mathrm{KCl}$ composite as electrolyte for intermediate temperature solid oxide fuel cells. Int. J. Electrochem. Sci. 2019, 14, 755-763. [CrossRef]

20. Guo, Y.; Liu, B.; Yang, Q.; Chen, C.; Wang, W.; Ma, G. Preparation via microemulsion method and proton conduction at intermediate-temperature of $\mathrm{BaCe}_{1-\mathrm{x}} \mathrm{Y}_{\mathrm{x}} \mathrm{O}_{3-\alpha}$. Electrochem. Commun. 2009, 11, 153-156. [CrossRef]

21. Vilela, C.; Martins, A.P.C.; Sousa, N.; Silvestre, A.J.D.; Figueiredo, F.M.L.; Freire, C.S.R. Poly(bis[2(methacryloyloxy)ethyl]phosphate)/bacterial cellulose nanocomposites: Preparation, characterization and application as polymer electrolyte membranes. Appl. Sci. 2018, 8, 1145. [CrossRef]

22. Xia, C.; Qiao, Z.; Feng, C.; Kim, J.; Wang, B.; Zhu, B. Study on zinc oxide-based electrolytes in low-temperature solid oxide fuel cells. Materials 2018, 11, 40. [CrossRef] [PubMed]

23. Fang, X.; Zhu, J.; Lin, Z. Effects of electrode composition and thickness on the mechanical performance of a solid oxide fuel cell. Energies 2018, 11, 1735. [CrossRef]

24. Bernuy-Lopez, C.; Rioja-Monllor, L.; Nakamura, T.; Ricote, S.; O’Hayre, R.; Amezawa, K.; Einarsrud, M.; Grande, T. Effect of cation ordering on the performance and chemical stability of layered double perovskite cathodes. Materials 2018, 11, 196. [CrossRef] [PubMed]

25. Morejudo, S.H.; Zanón, R.; Escolástico, S.; Yuste-Tirados, I.; Malerød-Fjeld, H.; Vestre, P.K.; Coors, W.G.; Martínez, A.; Norby, T.; Serra, J.M.; et al. Direct conversion of methane to aromatics in a catalytic co-ionic membrane reactor. Science 2016, 353, 563-566. [CrossRef] [PubMed]

26. Duan, C.; Tong, J.; Shang, M.; Nikodemski, S.; Sanders, M.; Ricote, S.; Almonsoori, A.; O’Hayre, R. Readily processed protonic ceramic fuel cells with high performance at low temperatures. Science 2015, 349, 1321-1326. [CrossRef] [PubMed]

27. Liu, F.; Dang, J.; Hou, J.; Qian, J.; Zhu, Z.; Wang, Z.; Liu, W. Study on new $\mathrm{BaCe}_{0.7} \mathrm{In}_{0.3} \mathrm{O}_{3-\delta}-\mathrm{Gd}_{0.1} \mathrm{Ce}_{0.9} \mathrm{O}_{2-\delta}$ composite electrolytes for intermediate-temperature solid oxide fuel cells. J. Alloy Compd. 2015, 639, $252-258$. [CrossRef]

28. Park, K.-Y.; Lee, T.-H.; Jo, S.; Yang, J.; Song, S.-J.; Lim, H.-T.; Kim, J.H.; Park, J.-Y. Electrical and physical properties of composite $\mathrm{BaZr}_{0.85} \mathrm{Y}_{0.15} \mathrm{O}_{3-\delta}-\mathrm{Nd}_{0.1} \mathrm{Ce}_{0.9} \mathrm{O}_{2-\delta}$ electrolytes for intermediate temperature-solid oxide fuel cells. J. Power Sources 2016, 336, 437-446. [CrossRef]

29. Rondao, A.I.B.; Patricio, S.G.; Figueiredo, F.M.L.; Marques, F.M.B. Composite electrolytes for fuel cells: Long-term stability under variable atmosphere. Int. J. Hydrog. Energy 2014, 39, 5460-5469. [CrossRef]

30. Martins, N.C.T.; Rajesh, S.; Marques, F.M.B. Synthesis and electrochemical assessment of $\mathrm{Ce}_{0.5} \mathrm{Yb}_{0.5} \mathrm{O}_{1.75}$ ceramics and derived composite electrolytes. Mater. Res. Bull. 2015, 70, 449-455. [CrossRef] 
31. Park, K.-Y.; Lee, T.-H.; Kim, J.-T.; Lee, N.; Seo, Y.; Song, S.-J.; Park, J.-Y. Highly conductive barium zirconate-based carbonate composite electrolytes for intermediate temperature-protonic ceramic fuel cells. J. Alloy Compd. 2014, 585, 103-110. [CrossRef]

32. Hei, Y.; Huang, J.; Wang, C.; Mao, Z. Novel doped barium cerate-carbonate composite electrolyte material for low temperature solid oxide fuel cells. Int. J. Hydrog. Energy 2014, 39, 14328-14333. [CrossRef]

33. Zhang, W.; Yuan, M.; Wang, H.; Liu, J. High-performance intermediate temperature fuel cells of new $\mathrm{SrCe}_{0.9} \mathrm{Yb}_{0.1} \mathrm{O}_{3-\alpha}$-inorganic salt composite electrolytes. J. Alloy Compd. 2016, 677, 38-41.

34. Shi, R.; Liu, J.; Wang, H.; Wu, F.; Miao, H. Intermediate temperature fuel cell durability of Eu-doped $\mathrm{SrCeO}_{3}-\mathrm{SrZrO}_{3}$ solid solution/ NaCl-KCl composite electrolyte. Ceram. Int. 2017, 43, 16931-16935. [CrossRef]

35. Song, J.; Meng, B.; Tan, X. Stability and electrical conductivity of $\mathrm{BaCe}_{0.85} \mathrm{~Tb}_{0.05} \mathrm{M}_{0.1} \mathrm{O}_{3-\delta}(\mathrm{M}=\mathrm{Co}, \mathrm{Fe}, \mathrm{Y}, \mathrm{Zr}$, $\mathrm{Mn}$ ) high temperature proton conductors. Ceram. Int. 2016, 42, 13278-13284. [CrossRef]

36. Shi, R.; Liu, J.; Wang, H.; Wu, F.; Miao, H.; Cui, Y. Low temperature synthesis of $\mathrm{SrCe}_{0.9} \mathrm{Eu}_{0.1} \mathrm{O}_{3-\alpha}$ by sol-gel method and $\mathrm{SrCe}_{0.9} \mathrm{Eu}_{0.1} \mathrm{O}_{3-\alpha}-\mathrm{NaCl}-\mathrm{KCl}$ composite electrolyte for intermediate temperature fuel cells. Int. J. Electrochem. Sci. 2017, 12, 11594-11601. [CrossRef]

37. Reddy, G.S.; Bauri, R. Y and In-doped $\mathrm{BaCeO}_{3}-\mathrm{BaZrO}_{3}$ solid solutions: Chemically stable and easily sinterable proton conducting oxides. J. Alloy Compd. 2016, 688, 1039-1046. [CrossRef]

38. Liu, X.; Fechler, N.; Antonietti, M. Salt melt synthesis of ceramics, semiconductors and carbon nanostructures. Chem. Soc. Rev. 2013, 42, 8237-8265. [CrossRef] [PubMed]

39. Matsuda, A.; Oh, S.; Nguyen, V.H.; Daiko, Y.; Kawamura, G.; Muto, H. Anhydrous proton conductivity of $\mathrm{KHSO}_{4}-\mathrm{H}_{3} \mathrm{PW}_{12} \mathrm{O}_{40}$ composites and the correlation with hydrogen bonding distance under ambient pressure. Electrochim. Acta 2011, 56, 9364-9369. [CrossRef]

40. Soo, M.T.; Prastomo, N.; Matsuda, A.; Kawamura, G.; Muto, H.; Noor, A.F.M.; Lockman, Z.; Cheong, K.Y. Elaboration and characterization of sol-gel derived $\mathrm{ZrO}_{2}$ thin films treated with hot water. Appl. Surf. Sci. 2012, 258, 5250-5258. [CrossRef]

41. Zhu, B.; Li, S.; Mellander, B.E. The oretical approach on ceria-based two-phase electrolytes for low temperature $\left(300-600^{\circ} \mathrm{C}\right)$ solid oxide fuel cells. Electrochem. Commun. 2008, 10, 302-305. [CrossRef]

42. Presto, S.; Viviani, M. Effect of $\mathrm{CuO}$ on microstructure and conductivity of Y-doped $\mathrm{BaCeO}_{3}$. Solid State Ion. 2016, 295, 111-116. [CrossRef]

43. Verma, M.L.; Minakshi, M.; Singh, N.K. Synthesis and characterization of solid polymer electrolyte based on activated carbon for solid state capacitor. Electrochim. Acta 2014, 137, 497-503. [CrossRef]

44. Chen, M.; Zhang, H.; Fan, L.; Wang, C.; Zhu, B. Ceria-carbonate composite for low temperature solid oxide fuel cell: Sintering aid and composite effect. Int. J. Hydrog. Energy 2014, 39, 12309-12316. [CrossRef] 